\title{
Drivers of export-led agriculture in Ghana: The case of emerging cashew production in Ghana's Brong Ahafo Region ${ }^{1}$
}

\author{
James Boafo \\ School of Social Science, University of Queensland \\ jamesknust@yahoo.com \\ Divine Odame Appiah \\ Department of Geography and Rural Development, \\ Kwame Nkrumah University of Science and Technology, Ghana \\ Peter Dok Tindan \\ Department of Geography and Rural Development, \\ Kwame Nkrumah University of Science and Technology, Ghana
}

\begin{abstract}
The Brong Ahafo region, often referred to as the 'breadbasket' of Ghana, in the last decade has become the centre of increasing expansion of cashew nuts production for export. Farmers in the region are increasingly devoting their time and lands to the production of raw cashew nuts for the export market instead of producing food for the local market. We adopt a political ecology approach to demonstrate how the historical legacy of export-led agriculture and its integration of local agriculture into the global market drives the production of cashew nuts in Ghana. Our analyses were informed by interview responses from farmers, and a review of critical agrarian scholarship, policy documents and cashew production and consumption reports. We find that historical legacies, government policy narratives and global market integration are driving the commodification of local agriculture in Ghana and conclude that there is an urgent need to plan for an agricultural transition that considers both immediate and long-term impacts.
\end{abstract}

\footnotetext{
${ }^{1}$ Sections of this paper are part of a $\mathrm{PhD}$ thesis submitted to the University of Queensland by the first author. We thank the University of Queensland for funding the Ph.D. study through the Australian Government Research Training Program Scholarship. We also thank the anonymous reviewers and editor for providing feedback on the manuscript.
} 


\section{Introduction}

Developing countries have acted as the global breadbasket, including as providers of raw agricultural commodities, over a long history dating back to at least fifteenth century colonial extractivist regimes (Campbell, 2013). To this day, many developing economies, including post-colonial economies, remain enrolled in the global economy as suppliers of cheap primary commodities (McMillan, Rodrik and Verduzco-Gallo, 2014). Despite the poor economic growth of commodity-dependent economies, especially compared to industrialised countries, governments of developing countries continue to target export-led agriculture as the basis for delivering exportoriented growth (Gwynne, 1999). The integration of the agricultural sectors of developing countries into the global economy as part of a broader structural transformation of agriculture is driven by multiple complex factors across different scales. To understand some of the factors, this paper ${ }^{2}$ provides an analysis of historical and contemporary agricultural production in Ghana through a case study of cashew nuts production in the Brong Ahafo region. ${ }^{3}$

The commercial production of cashew nuts in Ghana is an emerging sector that to date has attracted limited academic attention. Evans, Mariwah and Antwi (2015) have investigated the gendered and generational power relations regarding land access, property rights and decision-making in a cashew growing community of Seketia, in the Brong Ahafo region. Amanor (2009) has examined how the development of tree plantation including cashew in the region has affected land tenure relations. Peprah et al. (2018) have analysed whether cashew nuts production will permanently reduce poverty among farmers in the region. Aside from these scholarly works, there are reports (see for instance Heinrich, 2012; Osei-Akoto, 2010) that have analysed the cashew value chain in Ghana. We advance these studies by analysing the drivers of cashew nuts production in Ghana.

This article adopts a political ecology approach (Offen, 2004; Peet, Robbins and Watts, 2011; Robbins, 2012; Watts, 2000, 1983) to analyse multiple factors including historical legacies, the role of the state, and global market forces shaping the livelihoods of peasants in Ghana. We base our argument largely on six-months of fieldwork conducted in 2016 with farmers

\footnotetext{
${ }^{2}$ Sections of this paper are part of a $\mathrm{PhD}$ thesis submitted to the University of Queensland, Australia by the first author.

${ }^{3}$ Note that after the fieldwork in 2016, the Brong Ahafo region was divided into three administrative regions, namely Bono East, Brong Ahafo and Ahafo through a referendum in 2018. In this paper, Brong Ahafo Region is a collection of the three regions. All the administrative regions mentioned below refer to regions of Ghana from 1982 to 2018.
} 
in the region and representatives from government, an analysis of the historical emergence of plantation agriculture, and a review of relevant cashew reports and government policy narratives. We find that the increasing production of cashew nuts in Ghana for export is shaped by historical legacies of the integration of farmers into the global market, government policy supports, and the current high demand for tree nuts at the global level due to the growing awareness of their health benefits. We conclude that while farmers may be earning seasonal incomes from the production of cashew nuts, continuous support for export-led agriculture is reinforcing traditional specialisation patterns that have reduced incentives to diversify the Ghanaian economy towards modern manufacturing.

We begin by providing an overview of the political ecology framework that has informed the research approach and analysis. This is followed by a brief review of the historical trajectories of export-led agriculture in Ghana with specific focus on cashew nuts production. We then introduce the case study, the Brong Ahafo region, and give an overview of the methods adopted for data collection and analysis. We then present our findings, including discussions of government policy narratives, key global trends of cashew consumption, and how all these are reinforcing export-led agriculture in Ghana, including production of cashew nuts for the export market.

\section{A political ecology approach}

The agrarian histories of Ghana shaped by colonisation have set the scene for a political ecology analysis of the processes shaping cashew nuts production in the country. Political ecology emerged in the 1970s and 1980s as a way of analysing the historical, political and economic processes shaping human-environment interactions (Schubert, 2005), using historical, power and scalar analyses to understand the multiple processes that shape environmental outcomes (Peet and Watts, 2004; Robbins, 2012; Watts, 1983; 2016). The approach emerged through analyses of the integration of former colonised states into the global economy through the colonial project, and emphasised the similarities between countries of the global South, which were widely understood as having been shaped by colonial legacies, trade regimes and global power dynamics (Hanna, Clark and Slocombe, 2008; Moseley, 2017). Among many concerns, political ecology insists that any explanation of environmental outcomes, particularly in former colonised states, must seriously consider questions linked to historical political economy, such as colonial economic policies, global market integration, the role of the state and private capitalist development. 
Reflecting this, we adopt a historical analytical approach in this paper to understand colonial legacies in driving the commodification of agriculture in Ghana. We adopts historical analysis (Campbell, 2013; Offen, 2004; Watts, 1983) of political ecology to analyse how colonial economic production has structurally tied Ghana's economy to the production of primary commodities and how these legacies continue to shape agricultural policies and narratives of the Ghanaian postcolonial state. By doing this, we aim to render transparent how the transfer of political economies and their attending ideologies from the metropole to colonies (such as Ghana) shaped patterns of resource use and livelihoods of local people (see also Offen, 2004).

We therefore analyse the historical developments of plantation agriculture in Ghana, and how it reconfigured the local economy from subsistence to an export-led economy (see next section). By doing this, we aim to establish a connection between colonial plantation development and the contemporary expansion of export-led agriculture in Ghana. In addition to drawing from historical narratives of plantation agriculture, we analyse current export-led agricultural policy narratives and how they reinforce historical legacies of export-led production - the latest of which is the production of cashew nuts for export. We also situate our analysis of cashew production within the global commodity market by analysing how the integration of Ghana into the global commodity chain as a supplier of primary commodities is incentivising cashew production.

Informed by the political ecology analytical approach, we argue that the increasing production of cashew nuts in Ghana is tied to colonial legacies of plantation development, global capitalist political economy - including growing international consumer demand for cashew nuts - and national neoliberal policies (see also Neumann 2009; Tan-Mullins 2007). We now review briefly the emergence of export-led agriculture in Ghana and how this has led to a commodity-dependent economy.

\section{History of plantation and cashew production in Ghana}

From the fifteenth century, the Gold Coast (now Ghana) was integrated into the global economy in three ways: through the supply of gold, through the supply of slaves for work in plantations in the new world, and through export crops (Campbell, 2013). Although slavery was abolished by the midnineteenth century, gold, timber and agricultural export commodities remained the major exports of Ghana for almost two centuries (Boame, 1998). Export-led agriculture in particular, introduced to Ghana by the Dutch in 1788, integrated the rural economy into the global economy (Awadzi et al., 2001). During this era, slaves became plantation labourers in the 
production of sugarcane, tobacco and other tropical commodities, for export to Europe (Awadzi et al., 2001). The rationale for the use of slave labour by the Dutch was to avoid the cost of transporting them to the new world, instead using them locally to produce agricultural commodities for export (Awadzi et al., 2001). However, the Dutch plantations failed to gain acceptance among smallholder farmers in Ghana for socio-cultural and ecological reasons (Awadzi et al., 2001; Yaro, Teye and Torvikey, 2016). For example, the plantation system comprised mainly tree crops requiring a long gestation period inconsistent with native perennial cropping, and so was out of step with the local economic and social systems, as well as communal land tenure arrangements.

Cocoa, however, introduced during British colonial rule by Tetteh Quarshie, a native of Ghana, gained wide acceptance among native farmers of the forest regions in the early part of the 1890s (Ludlow, 2012). The British colonial government actively supported its production, and thousands of cocoa tree seedlings were sold to smallholder farmers by the 1890s (Ludlow, 2012). On this basis, cocoa production gradually spread across the whole of Ashanti - a region that became the centre of economic activities in the colonial days, continuing to the present day because of its natural resource endowments (Berry, 1993; Whitfield, 2018). The export of native-grown cocoa to Europe integrated Ghanaian family farmers into the global economy (Grier, 1981), especially when the second industrial revolution in Europe created markets for tropical commodities including cocoa (Austin, 2007). This incentivised farmers in Ghana to expand production into new frontiers, producing about $40 \%$ of the world's cocoa demand by the 1920 s (Green and Hymer, 1966; Whitfield, 2018). During the Second World War, the British colonial government monopolised the cocoa market by buying and selling cocoa beans to the British Ministry of Food (Leith and Soderling, 2000).

Reflecting this, the Ghanaian economy became an extension of the economies of Britain and other European nations, through the supply of raw materials (for example, cocoa) to feed their industries during the colonial period (Berry, 1993; Whitfield, 2018). This system of production that emerged ensured the colony's economy remained integrated into the global economy in a peripheral way, through the supply of export commodities in the postcolonial period. Since economies involve countless deliberate individual decisions (Bell, 2012), it can be argued that the structure of Ghana's economy characterised by export of primary commodities is an economic and political construct by European colonial masters, and emerging through the dynamics and distribution of global power. The colonial economic design has tied both the national and local economies to 
the production of export commodities as dominant economic activity. The colonial production systems commoditised land and commercialised social production relations as well as dislocated the local subsistence economy, producing famine in former colonised African states (Campbell, 2013; Rodney, 1973; Watts, 1983).

At independence in 1957, cocoa was a major source of national revenue, contributing about $60 \%$ of the nation's foreign exchange earnings (Sowa, 1991). Successive governments in the postcolonial era supported the production of cocoa and encouraged a diversification of the export-base through the introduction of new export crops to widen participation in international trade to achieve export-oriented growth. Cashew was introduced in the 1960s as part of the diversification strategy but production failed due to several challenges including lack of markets and inadequate support from government (Government of Ghana (GoG), 2000). However, within the same period there was an acceleration of cashew production in Côte d'Ivoire, which is now the world's largest exporter - mainly to India and Vietnam - of raw cashew nuts (Kone, 2010). Cashew nuts production expanded gradually into Ghana's Brong Ahafo region through farmer networks in the late 1970s from communities along the Ghanaian-Ivorian border, such as Banda, Seikwa, and Kejetia (Amanor, 2009; Evans, Mariwah and Antwi, 2015).

In the 1980s, Ghana adopted structural adjustment programmes that liberalised the commodity market and incentivised the production of export commodities in particular (Moseley, Schnurr and Bezner Kerr, 2015; Yaro, Teye and Torvikey, 2016). Cashew nuts became one of the non-traditional commodities developed as part of the government's export diversification strategy (GoG, 2000). Farmers were incentivised through the liberalisation of export markets to re-establish abandoned cashew farms and establish new ones. Through these supports for market and production, Ghana exported 15 metric tonnes of cashew nuts in 1991, marking the beginning of cashew export from Ghana (GoG, 2000). By 1997, the quantity of export had increased to 3,571 metric tonnes (GoG, 2000).

The increasing interest in cashew production culminated in the commissioning of a study by the Ghanaian Ministry of Food and Agriculture in 1998 to assess the status and potential of cashew nuts production in the country. It found that Ghana had endowed potentials including available land to increase the area under cultivation of cashew. More than three million hectares of land was thought to be suitable, largely in the Northern and Brong Ahafo regions. The study also rationalised the production of cashew as necessary to increase income of farmers, leading to poverty alleviation (GoG, 
2000). With these outcomes from the study, the government implemented the Cashew Development Project in 2002 with the aim of increasing production across five regions. Despite the implementation of the project in all these regions, production of cashew nuts is largely concentrated in the Brong Ahafo region.

There have also been efforts from donor agencies and Non-Governmental Organisations to support production of cashew nuts and other tree crops in the region. For instance, Adventists Development and Relief Services (ADRA), Technoserves, the United States Agency for International Development (USAID), and the German Development Agency (GIZ) have all played important roles in promoting cashew and tree crop production in the Brong Ahafo region (African Cashew Alliance (ACA), 2016; Amanor, 2009). Through this state and non-state support, Ghana currently produces about 70,000 metric tonnes of cashew nuts annually (World Cashew Convention, 2017). Cashew has become a leading non-traditional agricultural export of Ghana with export revenue in 2016 of US\$197 million (Ghana Business News, 2018). Although the nation as well as farmers continue to earn revenue from export-led agriculture, our major concern is to bring to light the historical and contemporary processes that continue to tie Ghana to this system of agriculture as the dominant economic activity. The next section introduces the case study and research methods that were adopted to gather data.

\section{The research case study}

Ghana is an agrarian economy, with almost $50 \%$ of the population engaged in the sector (FAO, 2015). As noted, export commodity production has a long history, dating back to the eighteenth century, and the production of export crops continues to dominate the agricultural sector, and the wider economy. Our study was conducted in the Brong Ahafo region, which produces about $30 \%$ of national food needs and leads in the production of local staples such as maize, yam and cassava (Amanor, 2009; Ghana Statistical Service, 2013). Urban dwellers in Ghana largely depend on food from this region (Amanor and Pabi, 2007). The region has become a major area in recent decades for the cultivation of tree crops such as mango, citrus, teak and cashew for both the domestic and export markets (Amanor, 2009). The production of cashew nuts in particular is one of the tree crops that is widely gaining acceptance among farmers there (Evans, Mariwah and Antwi, 2015; Peprah et al., 2017).

Fieldwork was conducted in four cashew-growing communities of the region namely Wenchi, Kintampo, Amponsahkrom and Nyakoma. These 


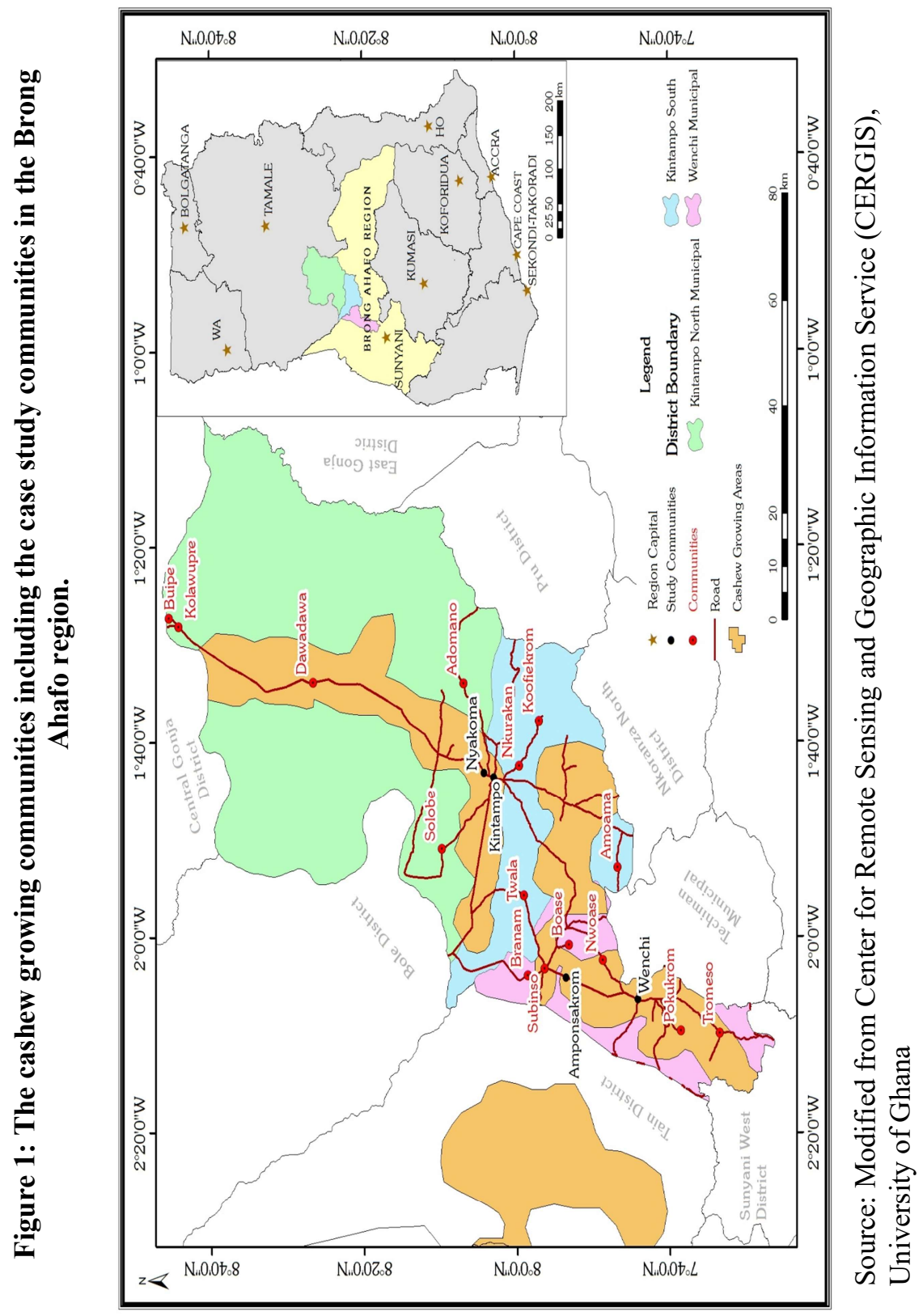


communities were selected on the basis that livelihood activities in them are undergoing transformation including the shifting of land and resources towards export-oriented agriculture. Figure 1 shows the cashew growing communities included in the case study.

We have adopted a qualitative case study design, including interviews, observation and document analysis to gather data from different actors involved in the cashew sector. The fieldwork was carried out over a sixmonth period (June 2016 to November 2016), when 39 cashew farmers, nine local agricultural actors, seven traditional/assembly members and one representative from the Ministry of Food and Agriculture participated in the study. The main themes of the interviews were focused on drivers of cashew nuts at the local level. Five cashew farms were also visited to observe the emerging land use changes. Each interview lasted for at least one hour, and was audio recorded with permission from the participants. The interviews were conducted in Akan, the most widely spoken language in the study communities. The first author, whose first language is Akan, undertook the fieldwork. The interviews were later transcribed into English, followed by coding and analysis.

Scholarly articles (for example, Amanor, 2009; Evans, Mariwah and Antwi, 2015; Peprah et al., 2017) and reports on cashew production from the African Cashew Alliance (ACA), the World Cashew Convention, and the International Center for Tropical Agriculture (CIAT) were reviewed. The tree crops policy of Ghana was also analysed to understand how government, with the support of donors, is driving export-led agriculture through policy narratives (Teye and Torvikey, 2018). We now present our findings.

\section{Government policy interventions drive cashew production}

In this section, we trace how government and donor-sponsored marketoriented policies, especially the tree crops policy and Cashew Development Project, are reinforcing the colonial and structural adjustment legacies of export-led agriculture in Ghana. The tree crops policy was designed in 2012 with the aim of providing a comprehensive approach for development of the tree crop sector. The policy was inspired by the view that cocoa contributes significantly to national revenue and that a well-developed tree crop sector can thus increase national revenue and contribute to economic growth. Despite the contributions of cocoa to national revenue, international and national development actors have argued that it is risky to rely on cocoa alone as a major source of foreign revenue, given the volatility of the global commodity market (Teye and Torvikey, 2018). The tree crops policy therefore represented a move to the diversification of export crops, with 
farmers encouraged to produce non-traditional export crops to increase their participation in the global commodity market. The government argues that Ghana has a number of comparative advantages in the production of a large number of tree crops including "political stability, geographic location and access to large regional and European markets, adequate seaports, [and] good agricultural environment (arable land, forests and water resources) suitable for the cultivation of different tree crops" (MOFA, 2012, p. 4).

In addition, the policy claims that increased prices of some commodities on the world market and improvements in private sector participation in the tree sector provide incentives to promote the production of specific export tree crops in the agroecological zones of the country. Demonstrating this, production of cashew is widely gaining acceptance in the transitional zone (Brong Ahafo) and northern savannah zones of Ghana, often justified on the basis of favourable climatic and vegetative conditions. One of the key assumptions underlying the tree crops policy is that the "poorest farmers who are prone to food insecurity and poverty are those whose incomes are highly dependent on a single commodity....with strong seasonal price variations and poor value chain organization" (MOFA, 2012, p. 5). Reflecting this fact, the policy argues that farmers in poor regions including Brong Ahafo need to diversify their production into export-oriented crops to generate additional income and, by default, enhance food security. Such policy narratives and assumptions have driven the promotion of cashew production throughout the Brong Ahafo and northern regions of Ghana.

The tree crops policy also aims to learn from, and replicate, previous interventions to develop tree crops in Ghana. One such intervention is the Cashew Development Project, implemented in the cashew growing areas in the 2000s. The project spanned eight years, during which 26,000 hectares of cashew farms were established. This was achieved through the distribution of improved cashew planting materials to farmers, as well as training them in cashew production techniques. Through this project, production of cashew has increased, particularly in the Brong Ahafo region.

Currently, production and multiplication of improved cashew planting materials are the work of the Wenchi Agricultural Research Station, one of the study communities. Its mandates include multiplication and trial of improved planting materials for farmers, alongside conservation of germplasm. The station also serves as a resource centre for farmers and researchers. The Chief Technical Officer of the station described how, during the Cashew Development Project, the station was tasked with producing improved cashew seedlings for farmers. He explained, "When we started, we were just preparing the ground and monitoring the crop to see how it behaves, 
so that if farmers come for advice, we will have something to tell them. We are now at a stage where we are cloning cashew planting materials and doing grafting for farmers to have grafted seedlings to plant" (Interview, 19/07/2016).

Further inquiries from the Chief Technical Officer revealed that the station has produced improved cashew planting materials (grafted) and sold to farmers at a low cost $(\mathrm{GH} \not 1.50)$ to attract more farmers to plant cashew. The price was low because the government subsidised it, as well as providing all the logistics needed to raise enough cashew seedlings for farmers. The Ministry of Food and Agriculture confirmed government support of raising cashew seedlings for farmers:

The Ministry supported the multiplication and distribution of 150,000 improved cashew planting materials at the Wenchi Agricultural Station and CRIG [Crop Research Institute of Ghana] Station at Bole to plant 750 hectares of land. The Ministry also maintained scions [graft] banks at the Wenchi, Bole and Nkwanta [stations] which serve as the main source of cashew nursery materials (Medium Term Expenditure Framework (MTEF), MOFA, 2018, p. 6).

As noted above, the increasing production and distribution of cashew seedlings to farmers is premised on a recommendation derived from a study that concluded Ghana had enough land to develop up to 100,000 hectares of new cashew farms by 2020 (GoG, 2000). This recommendation - alongside the broader consideration that cashew production represented an export diversification strategy to increase national revenue and incomes of farmers as well as enhance food security - led to implementation of the Cashew Development Project in the 2000s. Despite the claim that land is available for cashew production, the tree crops policy acknowledges that access to land is a hindrance to development of tree crops, given the complex nature of the customary land tenure system in Ghana. This is true, and indeed the expansion of cashew production appears to be reinforcing the complexity of customary land tenure systems, including land concentration and accumulation by local elites in the Brong Ahafo region (Amanor, 2009; Boafo and Lyons, forthcoming; Evans, Mariwah and Antwi, 2015).

The discussion so far demonstrates that through policy supports, government and donors are promoting the production of cashew nuts in Ghana. The narratives of the tree crops policy in particular are reinforcing colonial and structural adjustment legacies of export-led agriculture as well 
as traditional specialisation patterns in Ghana. Thus through government and donor supports, Ghana continues to demonstrate a comparative advantage in the production of primary commodities, an economic structure that has provided few incentives to diversify into manufacturing since the eighteenth century (McMillan, Rodrik and Verduzco-Gallo, 2014). While specialising in the production of primary commodities for export has not provided any gainful employment opportunities or even driven rapid growth and transformation of the economy, planning of the Ghanaian economy continues to reinforce such traditional production patterns with outcomes that often (re)produce poverty among farmers (Amanor, 2009; Austin, 2007, 2010; Yaro, Teye and Torvikey, 2016, 2017). Support by government for the development of tree crops is premised on the fact that there is high global demand for commodities, particularly tree nuts. We now turn to analyse how global demand for cashew nuts is driving its production in Ghana.

\section{High global cashew demand drives cashew production in Ghana}

Global demand for cashew nuts has been growing at a rate of $7 \%$ per annum over the last decade, and demand for cashew kernels - processed from raw cashew nuts - is expected to grow by $85 \%$ in the years ahead (Heinrich, 2012; World Cashew Convention, 2017). The world's largest consumers of cashew nuts are concentrated in India, the United States, Europe, the United Arab Emirates and Australia. India alone consumes around 200,000 metric tonnes of cashew nuts per year, making it the world's largest consumer (Rabany, Rullier and Ricau, 2015). The United States is the second largest consumer, with an annual consumption level of about 150,000 metric tonnes, followed by Europe, which consumes 110,000 metric tonnes. In China, the growing middle class provides a sizeable market for cashew nuts, with an annual consumption rate of 50,000 metric tonnes. The United Arab Emirates and Australia each consume 15,000 metric tonnes per year (Rabany, Rullier and Ricau, 2015). These consumption rates are predicted to remain high due to the growing awareness of the health and nutritional benefits of cashew nuts (World Cashew Convention, 2018). In addition, the growing consumption of vegan diets has induced high demand for products of tree nuts - such as cashew nut milk and cheese - that are used as substitutes for dairy products.

Except for India, the major cashew consuming countries are not major producers - an indication that consuming countries largely depend on cashew nuts produced from the global South. For instance, Africa - where cashew is not a staple - currently produces more than $50 \%$ of the world's cashew demand (Ghana News Agency, 2018). About 90\% of cashew nuts produced in Africa is exported in its raw form mainly to India and Vietnam, where it 
is processed into cashew kernels and exported to Europe, the United States, the Middle East and China for onward processing and consumption (Africa Cashew Alliance, 2016; Oteng, 2011). Currently India and Vietnam together process about $90 \%$ of global raw cashew nuts and are the two largest exporters of cashew kernels to these consuming countries (Trade for Development Centre, 2018). The growth of Indian and Vietnamese cashew sectors - resulting from increasing consumer demand for cashew nuts in the global North - has led to sourcing of raw cashew nuts from Africa to meet the high processing requirements (Tessmann and Fuchs, 2016). The African cashew sector in particular became attractive to the Asian traders and processors because at the initial stage, there was no official reference price of raw cashew nuts - an incentive that offered unique opportunities to Asian traders (Tessmann and Fuchs, 2016). For instance, 75\% of India's raw cashew nuts imports came from West Africa in 2016 (International Nut and Dried Fruit Council Foundation, 2017/2018). The huge importation of cashew nuts from Africa was confirmed by Mr. P Sundaran, chairperson of the Cashew Export Promotion Council of India. He stated that India is not self-sufficient in the production of raw cashew nuts as the processing capacity of the country is more than double the production, and the huge production deficit is met by imports "mainly from African countries" (World Cashew Convention, 2017, p. 24).

While India imports more than half of its annual processing requirement from Africa, Vietnam has overtaken India as the largest importer of raw cashew nuts from Africa, importing 1.1 million metric tonnes from the continent in 2017 (Xinhua, 2017). The huge processing requirements of both India and Vietnam suggest that there is an intense competition between the two countries over raw cashew nuts in Africa. The competition is further intensified by demand from local cashew processors, a process that drives the farm gate price of cashew nuts higher, thereby incentivising farmers to shift from food production to cashew nuts in African countries. Asian cashew exporters, rather than local processors are better able to afford the high farm gate price of raw nuts because the former can access credit facilities at preferential interest rates from their countries (see also Tessmann and Fuchs, 2016).

Interviews with farmers in Ghana's Brong Ahafo region revealed that they became aware of the high global demand for cashew nuts through the presence of Asian cashew exporting companies at the local level. As noted above, the cashew market expanded into Ghana from neighbouring Côte d'Ivoire, the world's largest exporter of raw cashew nuts (Kone, 2010; OseiAkoto, 2010). Côte d'Ivoire taxes the export of raw cashew nuts, but the 
Ghanaian export market has no such tax (Kone, 2010), resulting in a proliferation of Asian cashew nut exporters in Ghana exposing farmers in the Brong Ahafo region to the high global demand for cashew nuts. The proliferation of Asian cashew nuts exporters at the local level was confirmed by the local chairperson of cashew farmers in Wenchi who noted that "the buyers of cashew nuts come from India, Vietnam, Indonesia and Europe, but the European buyers buy only the processed cashew nuts [kernels] while the Asian buyers buy the raw nuts and export to their countries to process" (Interview, 27/06/2016). In two separate interviews in Amponsahkrom and Kintampo, two farmers explained that availability of market is largely incentivising production of cashew nuts in their communities. In Amponsahkrom, a farmer indicated that there is "a ready market for cashew nuts, if you harvest today, you will sell today. This is because during the cashew harvesting season, the buyers come here to buy the nuts" (Interview, 02/09/2016). Another farmer in Kintampo reiterated that many farmers were planting cashew "because of the availability of market for cashew nuts" (Interview, 16/09/2016). These findings resonate with the International Trade Centre (2015) report which documents that African farmers' interest in the cashew sector relates to the availability of ready market due to the high import demand for raw cashew nuts by Asian processors.

During the cashew harvesting season - February to April each year-local agents buy the raw cashew nuts at an agreed farm gate price, and then onward sell to the export companies. The farm gate price of cashew is determined through a negotiation between lead farmers and local cashew buying agents, and is based on international rates. Although the process of determining the price of farm produce in Ghana is understood as reducing profit margins accrued by farmers, many of them explained they had never received farm gate prices as high as those received for cashew nuts. The local chairperson of cashew farmers in Wenchi, who was involved in the negotiation of the price, revealed in an interview that in 2016 "a kilo of cashew nuts was selling at $\mathrm{GH} \notin 5$, so 50 kilos of cashew nuts was $\mathrm{GH} \phi 250$, which was high. Because of this, farmers are now moving into the production of cashew nuts" (Interview, 27/06/2016). Although farmers earn income from cashew nuts production, this income is seasonal, as it is only realised during the cashew harvesting season. This means that cashew does not bring all-year round income, an indication that cashew cannot permanently reduce poverty among farmers in the Brong Ahafo region (see also Peprah et al., 2017). Despite earning only seasonal income from cashew, land in the region is increasingly being tied to cashew production thereby limiting available land for food 
production, an all-year round livelihood activity (see also Boafo and Lyons, forthcoming; Evans, Mariwah and Antwi, 2015).

The discussion so far indicates that multi-scalar processes and actors are shaping the production of cashew nuts in Ghana for export. The processes and actors include government national policy interventions and high global demand for cashew nuts, demonstrated at the local level through the proliferation of Asian cashew exporters. With such a proliferation in Africa in the past decade, it can be argued that the neoliberalised agricultural regime does not always benefit developed economies only, but also powerful emerging economies in Asia that have sought to expand access to global markets to sustain high economic growth (Debrah, Yeboah and Boafo, 2015). The scramble for commodities, including cashew nuts in Africa by the Asian processors, reinforces traditional specialisation patterns that emerged during the expansion of mercantile colonisation in Africa. Such processes have further deepened the vulnerability of African peasant farmers to market integration and its exploitative relations. Demonstrating this market integration, cocoa production in the colonial days was marked by the significant integration of family farmers into the global market economy, as European merchants bought and shipped cocoa beans to feed industries in Europe (Grier, 1981).

The global cashew value chain, which occurs in different parts of the world as seen above, demonstrates a globalised food system as a result of the economic integration of regions. Africa became part of the global economy system during the expansion of mercantile colonisation and a global system continues to shape political and economic decisions in African countries. Thus, production of cashew nuts in African countries such as Ghana, Cote d'Ivoire, Nigeria, Guinea-Bissau, Kenya and Tanzania reflects these colonial legacies of export-led agriculture and global market integration, including through Asian traders buying and exporting cashew nuts produced by local farmers.

\section{Discussion and Conclusions}

In this paper, we adopted a historical perspective of political ecology to analyse the processes shaping the expansion of cashew production in Ghana's Brong-Ahafo region. We have argued that the expansion of cashew production is the latest manifestation of the legacies of colonial and postcolonial practices that have shaped and still shape export-led agriculture and global market integration. Colonial rule in Ghana and much of Africa was characterised by the extensive development of export crops as raw materials for a rapidly industrialising Europe (Austin, 2010; Campbell, 2013; 
Settles, 1996). Primary commodities from colonies including Ghana drove the industrial revolution and increased efficiency of machine production; they were also used in the manufacturing of consumer goods (Settles, 1996). The continuous demand for tropical commodities in developed economies has traditionally tied land use in developing countries to the production of export commodities, even in the postcolonial era. Development economists argue that countries with comparative advantage or specialisation in the production of primary commodities are at a distinct disadvantage because such a specialisation reduces incentives to diversify towards modern manufacturing (McMillan, Rodrik and Verduzco-Gallo, 2014). This partly explains why Ghana has not yet achieved productivity-enhancing structural changes (McMillan, Rodrik and Verduzco-Gallo, 2014).

We have also demonstrated that although the production of export commodities in Ghana is a colonial legacy, this legacy does not benefit only the colonial masters but also emerging economies in Asia that are seeking to expand access to natural resources in Africa to industrialise their economies (Cheru and Obi, 2010; Debrah, Yeboah and Boafo, 2015). The proliferation of Asian cashew buyers in Ghana provides market opportunities for local cashew farmers but also further integrates them into the global market and reinforces traditional specialisation patterns of commodity production. This specialisation has not, however, yet provided the needed economic transformation evident in job creation, poverty reduction and high standards of living in the country (Kolavalli et al., 2012; McMillan, Rodrik and Verduzco-Gallo, 2014). The integration of local farmers in Ghana into the global markets renders them indecisive as to what crops to produce; the choice of crops is decided, rather, by the market. Thus, the decisions of local farmers are largely formed in a predetermined market, a process that leaves them vulnerable to the forces of the global market.

We have seen how global market forces are shaping the decisions of farmers in the Brong Ahafo region of Ghana to shift resources into the production of cashew nuts for the global market rather than produce food for the local market. As Lawrence (2017) and Rosin, Stock, and Campbell (2012) argue, farmers in many parts of the global South are increasingly abandoning local food production to cultivate commodities that can be exchanged for money on the international market. Although farmers earn seasonal incomes from the production of cashew nuts in the case we have examined, it is unclear this situation will continue. It will depend upon factors including income levels and the purchasing power of the growing middle classes and their associated consumer demand for cashew nuts in the emerging economies. Consumption patterns, for example, may shift towards 
new commodities, thereby reducing the demand for cashew nuts. At the producer level, farmers may also either benefit or lose from government trade regulations, barriers and border interventions. The entire value chain of cashew rests on such factors, which amount to a volatile future for the sector.

Despite the uncertainty of the global commodity market, investment in cashew nuts production will likely continue to grow at the expense of local food production, with outcomes that may threaten local and national food supply, and reinforce land commodification (see Boafo and Lyons, forthcoming; Evans, Mariwah and Antwi, 2015). These impacts require further research and public policy attention, with a particular focus on ensuring national and regional agricultural policies commensurate with ensuring local food security. Further consideration should also be directed towards the opportunities for investment in the cashew sector to build incountry processing and encourage value addition, thereby leveraging further economic opportunities for Ghana in the face of a still-growing value chain for cashew production.

\section{References}

African Cashew Initiative. (2010). A value chain analysis of the cashew sector in Ghana. Deutsche Gesellschaft für Technische Zusammenarbeit (GTZ).

African Cashew Alliance. (2016). Growing the African cashew industry, annual report. http://www.africancashewalliance.com/sites/default/ files/documents/aca-annual-report-2016-en-web.pdf

Amanor, K. S. (2009). Tree plantations, agricultural commodification, and land tenure security in Ghana. In J. Ubink, A. Hoekema and W. Assies (eds.) Legalising land rights: Local practices, state responses and tenure security in Africa, Asia and Latin America, (pp. 133-162). Leiden: Leiden University Press.

Amanor, K. S. and Pabi, O. (2007). Space, time, rhetoric and agricultural change in the transition zone of Ghana, Human Ecology 35, 51-67.

Austin, G. (2007). Labour and land in Ghana, 1874-1939: a shifting ratio and an institutional revolution, Australian Economic History Review, 47 (1), 95-120.

Austin, G. (2010). African economic development and colonial legacies, International Development Policy 1, 11-32. http://poldev. revues.org/78

Awadzi, W. T., Bredwa-Mensah, Y., Breuning-Madsen, H. and Boateng, E. (2001). A scientific evaluation of the agricultural experiments at 
Frederiksgave, the Royal Danish Plantation on the Gold Coast, Ghana, Danish Journal of Geography 101, 33- 42.

Awanyo, L. (2001). Labor, ecology, and a failed agenda of market incentives: The political ecology of agrarian reforms in Ghana, Annals of the Association of American Geographers, 91(1), 91-121.

Bell, M. M. (2012). An invitation to environmental sociology. Thousand Oaks, California: SAGE.

Berry, S. S. (1993). No condition is permanent: The social dynamics of agrarian change in Sub-Saharan Africa. Madison, Wisconsin: University of Wisconsin Press.

Boafo, J. and Lyons, K. (forthcoming). Expanding cashew nut exporting from Ghana's Breadbasket: A political ecology of changing land access and use, and impacts for local food systems. International Journal of Sociology of Agriculture and Food.

Boame, K. A. (1998). Primary-export led growth: The evidence of Ghana, Journal of Economic Development, 23(1), 175-194.

Campbell, O. M. (2013). The political ecology of agricultural history in Ghana. [New York]: Nova Science.

Cheru, F. (2014). Emerging economies and Africa's natural resources: Avoiding the resource curse and building more resilient societies. [Canada]: North South Institute. http://www.nsi-ins.ca/wpcontent/uploads/2013/05/12.-Fantu-Cheru.pdf

Cheru, F. and Obi, C. (2010). The rise of China and India in Africa: Challenges, opportunities and critical interventions. Uppsala, Sweden: Nordic Africa Institute.

Debrah, I. O., Yeboah, T. and Boafo, J. (2015). Development for whom? Emerging donors and Africa's future, African Journal of Economic and Sustainable Development, 4(4), 308-327.

Evans, R., Mariwah, S. and Antwi, K. B. (2015). Struggles over family land? Tree crops, land and labour in Ghana's Brong-Ahafo region, Geoforum, 67, 24-35.

FAO (Food and Agriculture Organisation). (2015). Country fact sheet on food and agriculture policy trends. Rome: Food and Agriculture Policy Decision Analysis (FAPDA).

Ghana Business News. (2018). Cashew earns Ghana $\$ 197$ million, becomes leading non-traditional export product. https://www.ghanabusiness news.com/2018/05/28/cashew-earns-ghana-197m-becomes-leadingnon-traditional-export-product 
Ghana Statistical Service. (2013). 2010 Population and housing census, regional analytical report, Brong Ahafo Region. Accra: Ghana Statistical Service.

GoG (Government of Ghana). (2000). Republic of Ghana. Cashew Development Project: Appraisal report. Abidjan: African Development Fund. https:/www.afdb.org/fileadmin/uploads/afdb/ Documents/Project-and-Operations/Ghana Cashew Development Project - Appraisal Report.pdf

Green, R. H. and Hymer, S. (1966). The introduction of cocoa in the Gold Coast: A study in the relation between African farmers and colonial agriculture experts. Center discussion paper No. 1. New Haven, CT: Economic Growth Center, Yale University.

Grier, B. (1981). Cocoa marketing in colonial Ghana: Capitalist enterprise and the emergence of a rural African bourgeoisie, Ufahamu: A Journal of African Studies, 10(1-2), 89-115.

Gwynne, N. R. (1999). Globalisation, commodity chains and fruit exporting regions in Chile, Tijdschrift voor Economische en Sociale Geografie, 1999, 90(2), 211-225.

Gyasi, E. (1996). The environmental impact and sustainability of plantations in sub-Saharan Africa: Ghana's experience with oil-palm plantations. In G. Benneh, W. Morgan and J. Uitto (Eds.), Sustaining the future: Economic, social and environmental change in Sub-Saharan Africa (pp. 343-57). Tokyo: United Nations University Press.

Hanna, K. S., Clark, D. A. and Slocombe, D. S. (2008). Transforming parks and protected areas: Policy and governance in a changing world. New York: Routledge.

Heinrich, M. (2012). Case study of the African Cashew Initiative-Focus: Ghana, lessons from working with new and multiple partners: emerging results. www.value-chains.org/dyn/bds/docs/824/DCED ACiGhana July2012.pdf

International Center for Tropical Agriculture. (2011). Predicting the impact of climate change on cashew growing regions in Ghana and Cote d'Ivoire: Final Report. Managua, Nicaragua: Decision and Policy Analyses Program, CIAT, September.

International Nut and Dried Fruit Council Foundation. (2017/2018). Nuts and dried fruits, Statistical Yearbook 2017-2018. Reus, Spain: International Nut and Dried Fruit Council Foundation. https://www. nutfruit.org/files/tech/1524481168_INC_Statistical_Yearbook_20172018.pdf 
International Trade Centre. (2015). Edible nut: Cashew, second quarter. Cashew Quarterly Bulletin.

Kolavalli, S., Robinson, E., Diao, X., Alpuerto, V., Folledo, R., Slavova, M., Ngeleza, G. and Asante, F. (2012). Economic transformation in Ghana: Where will the path lead? IFPRI Discussion paper ; 01161. Washington, DC: International Food Policy Research Institute.

Kone, M. (2010). Analysis of the cashew sector value chain in Côte d'Ivoire. Eschborn, Germany: Deutsche Gesellschaft für Internationale Zusammenarbeit (GIZ).

Lawrence, G. (2017). Re-evaluating food systems and food security: A global perspective, Journal of Sociology, 53(4), 774-796.

Leith, J. C. and Söderling, L. (2000). Ghana: Long-term growth, atrophy, and recovery. Paris: OECD.

Ludlow, H. (2012). Ghana, cocoa, colonialism and globalisation: Introducing historiography, Yesterday and Today, (8), 1-21.

McMillan, M., Rodrik, D. and Verduzco-Gallo, I. (2014). Globalisation, structural change, and productivity growth, with an update on Africa, World Development 63(1), 11-32.

MOFA (Ministry of Food and Agriculture). (2012). Tree crops policy of Ghana. Accra, MOFA.

MOFA (Ministry of Food and Agriculture). (2018). Medium term expenditure framework for 2018-2021, Programme based budget estimates for 2018. Accra, MOFA.

Moseley, W. (2017). The new Green Revolution for Africa: A political ecology critique, Brown Journal of World Affairs, 23(2), 177-190.

Moseley, W., Schnurr, M. and Bezner Kerr, R. (2015). Interrogating the technocratic (neoliberal) agenda for agricultural development and hunger alleviation in Africa, African Geographical Review, 34(1),1-7.

Neumann, R. P. (2009). Political ecology: Theorising scale, Progress in Human Geography, 33(2), 398-406.

Offen, K. H. (2004). Historical political ecology: An introduction, Historical geography, 32, 19-42.

Osei-Akoto, S. (2010). A value chain analysis of the cashew sector in Ghana. Eschborn, Germany: Deutsche Gesellschaft für Internationale Zusammenarbeit (GIZ), for the African Cashew Initiative.

Oteng, S. (2011). Export factsheet ECOWAS: Cashew nuts. International Trade centre.http://www.intracen.org/uploadedFiles/intracenorg/Cont ent/About ITC/Where are we working/Multi-country programme s/Pact_II/111129-Export-Factsheet-Cashew\%20with\%20shell. pdf. 
Peet, R. and Watts, M. (2004). Liberation ecologies: Environment, development and social movements, second ed. London: Routledge.

Peet, R., Robbins, P. and Watts, M. J. (eds.) (2011). Global political ecology. London: Routledge.

Peprah, P., Amoako, J., Adjei, O. P. and Abalo, M. E. (2018). The syncline and anticline nature of poverty among farmers: Case of cashew farmers in the Jaman South District of Ghana, Journal of Poverty, 22(4), 355-377.

Rabany, C., Rullier, N. and Ricau, P. (2015). The Africa cashew sector in 2015: General trends and country profile. Analysis of cashew production, processing and trade in Africa. RONGEAD for the African Cashew Initiative.

Robbins, P. (2012). Political ecology: A critical introduction. Second edition. Chichester, UK: Wiley.

Rodney, W. (1973). How Europe underdeveloped Africa. London: BogleL'Ouverture ; Dar-es-Salaam: Tanzanian Publishing House.

Rosin, C., Stock, P. and Campbell, H. (eds.) (2012). Food systems failure: The global food crisis and the future of agriculture. London: Earthscan.

Schubert, J. (2005). Political ecology in development research: An introductory overview and annotated bibliography. Bern, Switzerland: NCCR North-South.

Settles, J. D. (1996). 'The impact of colonialism on African economic development', Honors Thesis Project, University of Tennessee, Knoxville.

Sowa, N. K. (1991). Monetary control in Ghana: 1957-1988. ODI Working Paper ; 45. London: Overseas Development Institute.

Tan-Mullins, M. (2007). The state and its agencies in coastal resources management: The political ecology of fisheries management in Pattani, southern Thailand. Singapore Journal of Tropical Geography $28,348-361$.

Teye, K. J. and Torvikey, G. D. (2018). The political economy of agricultural commercialisation in Ghana: A review, APRA Working Paper 15. Future Agricultures Consortium/APRA. https://www.futureagricultures.org/publications/working-papers-document/the-politicaleconomy-of-agricultural-commercialisation-in-ghana-a-review

Tessmann, J. and Fuchs, M. (2016). Loose coordination and relocation in a South-South value chain: Cashew processing and trade in southern India and Ivory Coast. Die Erde: Journal of the Geographical Society of Berlin, 147(3), 209-218. 
Trade for Development Centre (2018). How Fairnamese cashew nuts can conquer a solid position in the world market: Developing supply and markets for Fairtrade cashew nuts from Vietnam. Brussels: TDC.

Watts, M. (1983). Silent violence: Food, famine and peasantry in northern Nigeria; Berkeley: University of California Press.

Watts, M. (2000). Political ecology. In E. Sheppard and T. Barnes (Eds.), $A$ companion to economic geography (pp. 257-274). Oxford: Blackwell.

Watts, M. (2016). From vulnerability to resilience: Hans-Georg Bohle's scholarship and contemporary political ecology. Die Erde: Journal of the Geographical Society of Berlin 147(4), 252-265.

Whitfield, L. (2018). Economies after colonialism: Ghana and the Struggle for Power. Cambridge: Cambridge University Press.

World Cashew Convention (WCC). (2017). Proceedings from World Cashew Convention, 9-11 February, Singapore.

World Cashew Convention (WCC). (2018). Proceedings from World Cashew Convention and exhibition, 1-3 February, Macau.

Xinhua (2017).Vietnam's cashew import, export surge in 2017. http://www.xinhuanet.com/english/2017-12/29/c 136859513.htm

Yaro, J. A., Teye, K. J. and Torvikey, G. D. (2017). Agricultural commercialisation models, agrarian dynamics and local development in Ghana. Journal of Peasant Studies, 44(3), 538-554.

Yaro, J. A., Teye, K. J. and Torvikey, G. D. (2016). Historical context of agricultural commercialisation in Ghana: Changes in land and labour relations. Journal of Asian and African Studies 53(1), 49-6 